\title{
Innovation Leadership for Sustainable Organizational Climate in Institution of Technical and Vocational Education and Training (TVET) in Malaysia
}

\author{
Norlaila Wati Osman*, Arasinah Kamis \\ Facuty of Technical and Vocational,Universiti Pendidikan Sultan Idris, \\ Tanjung Malim, Perak, Malaysia \\ *Corresponding author: norlaila74@yahoo.com.my
}

DOI: https://doi.org/10.37134/ajatel.vol9.no1.6.2019

Published: 29 June 2019

\begin{abstract}
The well-being in and performance of an organization is often associated with a leadership who is assertive and innovative. Additionally, the well-being of innovative organizational climate also relates on how innovative leader leads the team. From this sustainable relationship between innovative with the subordinates, it will create a harmonic balance within the organization. This systematic literature review will examine the issues, and challenges and the appropriate leadership styles of the innovation leadership in creating an innovative and sustainable organizational climate in the institutions of Technical and Vocational Education, and Training (TVET) in Malaysia. A number of studies have been carried out by researchers in respect of the innovation leadership attributes associated with a variety of leadership styles viewed from different perspectives. Innovation leadership plays an important role in improving organizational performance. Therefore, the development of innovative leadership needs to develop innovative thinking among the team members to ensure their successfulness and remains competitive in the face of a rapidly changing world and the latest technology.
\end{abstract}

Keywords: Innovation Leadership, Sustainable Relationship, Organizational Climate, Technical and Vocational Education, and Training

\section{INTRODUCTION}

Related research of organizational climate was initiated in late $1950 \mathrm{~s}$, where social science researchers have made studies relating changes in the workplace environment. The term climate was used officially as a general notion for expressing the quality of sustainable and harmonious atmosphere in an organization (Tagiuri \& Litwin, 1968). Organizational climate was developed in the field of social psychology and organizational management to describe the patterns of psychological and social experiences in workers of an organization. The study by Watt (2002) associates an organization with innovation, and innovation in the organization requires a specific culture and climate. While, Holloway (2012) found that certain leadership behavior has an impact on several dimensions of the organizational climate. Educational leadership today faces complex issues every day, and educational leadership are compelled to become more creative and innovative so that they can keep in with the current economic realities (Marron, 2014). Leadership is an art and the process of influencing individuals or the society towards achieve a goal (Zaidatol Akmaliah \& Amir Sadeghi, 2012).

Educational leadership plays a very important role in shaping and developing the culture and innovative organizational climate. A specific leadership strategy can affect an individual's creativity and change of mindset in the following manner increase the subordinate's effectiveness and participation as well as improving the psychological capital - confidence, hope, and endurance - (Tummers and Kruyen, 2014); generate new thinking, and act differently in the ways of leading, managing and coordinating the 
team member which in turn can lead to more innovation in the development of products and services (Horth \& Buchner, 2014).

This critical review examines the issues, and challenges and the appropriate leadership styles of innovation leadership, the findings of which can be utilized to create an innovative and sustainable organizational climate in the Malaysia institutions of Technical and Vocational Education, and Training (TVET). The researches have been carried out by researches in respect a number of studies of innovation leadership attributes associated with a variety of leadership styles viewed from different perspectives.

\section{METHODS}

A systematic literature review was carried out whereby, relevant literature review is used to collect data for this research. This paper is written based on the relevant information extracted from previous studies, reference books, journal articles, conference paper and proceedings of seminar.

\section{RESULT AND DISCUSSION}

\section{Issues and Challenges of Leadership in TVET}

For the success of a programed transformation, all the members of an organization must always be ready to implement the initiatives and put in efforts. Readiness for changes, at the individual level or at the organizational level, is critical in achieving the objectives of the transformation outlined (Mua'azam, Yahya, \& Siti Noor, 2016). Next, availability of staff of an certain level to implement the initiatives strategist remains a question in the transformation of the vocational institutions (Irdayanti, Ramlee, \& Abdullah, 2015). A study conducted by Suriyati Yaapar (2018) found that teachers of Vocational Colleges are moderately concerned about the awareness of the transformation of the Technical and Vocational Education, and Training (TVET). TVET teachers are not well exposed to information relevant to the implementation of the TVET transformation. The research shows that some senior people are demotivated, and resistant to change; at the same time, the morale among the staff and personnel is low (Hadijah, 2015).

According to Alsolami, Guan Cheng, and M. Ibn Twalh (2016), it is a daunting task to implement an innovation successfully, innovation as a realistic goals cannot be reached could not be solved without the availability of appropriate leadership. A study by Terblanche (2017) on leadership capacity in an institution of TVET in South Africa found that the college leadership program requires TVET to help leaders in bringing changes to the curriculum.

In summary, some of the issues that challenges the leaders to create an innovative and sustainable organizational climate are as follows:

a. The readiness for change of individual in TVET organizations is critical.

b. The availability of staff to implement the initiatives strategist remains a question.

c. The awareness of teachers of the TVET transformation are in moderately concerned.

d. The teachers are not well-exposed to the information of TVET.

e. Senior people are demotivated.

f. Senior people are resistant to change.

g. The morale among the staff and personnel in TVET is low.

Therefore, leaders play an important role in influencing subordinates to implement any changes that occur in TVET. As such, the innovation leadership are highly recommended in implementing innovation and creativity to reach the realistic goals of an innovative and sustainable organizations. 


\section{Innovation Leadership in TVET}

Leadership is an innate or latent ability to gain the trust of people and every individual has it; it exists in the generic form but can be harnessed to meet a specified function or condition (Khodori, 2013). Good leadership has the potential to promote innovation in an organization by motivating the employees to think and work smartly; the leader is capable of fostering an atmosphere conducive to the development of innovative and creative skills, that will ultimately lead to increased productivity in, and competitive advantage of the organization (Elrehail, Emeagwali, Alsaad, \& Alzghoul, 2018).

Innovation leadership is all about inspiring people to have an open mind-set that drives the people to discover new things or new ways of working in an organization (Stevenson \& Kaafarani, 2012). Innovation leadership involves synthesizing different leadership styles within the organization to influence employees to produce creative ideas, products, services and solutions (Daniel, 2013). An innovative leader know the process of creating a roadmap, relationships, and commitment needed to plan and implement something new that will add value to the organization (Alsolami et al., 2016). The ability of a leader to innovate continuously to provide the necessary skills, and knowledge and creative efforts is the key to a competitive and sustainable organization (Mokhber, Khairuzzaman, \& Vakilbashi, 2018). Alsolami et al., (2016) suggest that leaders play a variety of roles while facilitating innovation in the organization, especially the role that stimulates creativity. An innovative organization is one that has a leader, who is always on the lookout for new ways to do things, including new processes, learning strategies and teaching techniques (Watt, 2002).

Woolley, Caza, and Levy (2011) studies various fields, including 828 workers of the education sector, and found there was a significant positive correlation between leading and positive work climate. The behavior of leaders has been identified as an important determinant of the organizational climate (Grojean, Resick, Dickson, \& Smith, 2004);, (Avolio \& Gardner, 2005); and described as an element that helps create and maintain a positive organizational climate (Avolio \& Gardner, 2005), (Gadner, Avalio, Luthan, \& May, 2005). Authentic leaders know how to boost the morale of people, foster effective communication channels, and support the organization with their personal values; , all these practices and efforts are the key to improve the organizational climate (Jones \& Crompton, 2009).

Based on the studies, researchers found that the appropriate leadership style to create the innovative and sustainable organizations are democratic leadership (Razak, Jaafar, Hamidon, \& Zakaria, 2014; (Martin, 2019); participative leadership (Somech, 2006; Zhou \& Wu, 2018); authentic leadership (Avolio \& Gardner, 2005)(Avolio \& Gardner, 2005; Azanza, Moriano, \& Molero, 2013; Elrehail et al., 2018; Jones \& Crompton, 2009; Schuckert, Kim, Paek, \& Lee, 2018; Woolley et al., 2011); transformational leadership (Alsolami et al., 2016; Babić, Savović, \& Domanović, 2014; García-Morales, Jiménez-Barrionuevo, \& Gutiérrez-Gutiérrez, 2012; ParaGonzález, Jiménez-Jiménez, \& Martínez-Lorente, 2018; Sarros, Cooper, \& Santora, 2008; Sheard, Kakabadse, \& Kakabadse, 2016); entreprenuerial leadership (Bagheri \& Pihie, 2012; Bhattacharyya, 2006; Jones \& Crompton, 2009; Kuratko, 2007; Richter, Jackson, \& Schildhauer, 2018; Roomi \& Harrison, 2011); innovative leadership (Irdayanti \& Ramlee, 2015; Feng, Huang, \& Zhang, 2016; Marron, 2014; Rahman, 2016; Watt, 2002); strategic leadership (Mua'azam et al., 2016; Schoemaker, Heaton, \& Teece, 2018; Zuraik, 2017). Table 1 shows the leadership styles that related to the innovative organizations.

Table 1 Leadership Styles Related to Innovative Organizations

\begin{tabular}{|c|c|c|}
\hline No. & Researchers & Leadership Style \\
\hline 1 & (Razak et al., 2014; Martin, 2019) & Democratic Leadership \\
\hline 2 & (Somech, 2006; Zhou \& Wu, 2018) & Participative Leadership \\
\hline 3 & $\begin{array}{l}\text { (Avolio \& Gardner, 2005)(Avolio \& Gardner, 2005; Azanza et } \\
\text { al., 2013; Elrehail et al., 2018; Jones \& Crompton, 2009; } \\
\text { Schuckert et al., 2018; Woolley et al., 2011) }\end{array}$ & Authentic Leadership \\
\hline 4 & $\begin{array}{l}\text { (Alsolami et al., 2016; Babić et al., 2014; García-Morales et } \\
\text { al., 2012; Para-González et al., 2018; Sarros et al., 2008; } \\
\text { Sheard et al., 2016) }\end{array}$ & $\begin{array}{l}\text { Transformational } \\
\text { Leadership }\end{array}$ \\
\hline 5 & $\begin{array}{l}\text { (Bagheri \& Pihie, 2012; Bhattacharyya, 2006; Jones \& } \\
\text { Crompton, 2009; Kuratko, 2007; Richter et al., 2018; Roomi \& }\end{array}$ & $\begin{array}{l}\text { Entrepreneurial } \\
\text { Leadership }\end{array}$ \\
\hline
\end{tabular}




\begin{tabular}{|c|c|c|}
\hline & Harrison, 2011) & \\
\hline 6 & $\begin{array}{l}\text { (Irdayanti \& Ramlee, 2015; Feng, Huang, \& Zhang, 2016; } \\
\text { Marron, 2014; Rahman, 2016; Watt, 2002) }\end{array}$ & Innovative Leadership \\
\hline 7 & $\begin{array}{l}\text { (Mua'azam et al., 2016; Schoemaker, Heaton, \& Teece, 2018; } \\
\text { Zuraik, 2017) }\end{array}$ & Strategic Leadership \\
\hline
\end{tabular}

\section{Innovative and Sustainable Organizational Climate}

Halpin \& Croft (1963), define organizational climate as the personality traits of an organization. Hoy and Miskel (2008) define organizational climate as a set of internal characteristics that distinguish a school from another school, and influence the internal characteristics of the organization. Holloway (2012), in turn defines the climate of an organization as a social and cultural environment that influences the behavior of people in it. One significant difference between the culture and the climate is that culture consists of the shared assumptions and ideology, while climate is defined as the perception of shared behaviors (Hoy, 2016). According to Madhukar (2017), some scholars define organizational climate as a function of a person and interaction with the organizational environment as well as independent variables that may be influenced by individuals or subjective perceptions. Other scholars mention the organization as an independent variable. Experts have defined organizational climate as patterns of repeated behaviors depending on values and atmosphere that exist in an organization from time to time.

Halpin \& Croft (1963) are pioneers in the study of organizational climate that reflects an individual's personality and how that person seeks to achieve a level of organization climate (Halpin, 1967). Sharma (2005) found that the climate for innovative organizations is categorised by the emphasis on quality, effective communication, teamwork, inter-departmental collaboration, reflection and support for innovation.

Hoy (2016) found the climate of the organization that produces the effective innovation process resulting from the institutional environment is safe, beautiful, and has enough space to learn as well as the provision of adequate facilities for the development of students," learning and instructors. According to Edokpolor \& Dumbiri (2019), leaders in TVET institutions need to work in partnership with stakeholders to create a more conducive teaching and learning environment. This factor is important because it influences the psychological and emotional well-being of, the instructors, students or supporting staff of an institution. Indirectly, it helps students acquire excellent achievement, and the teaching staff and other personnel will also feel the thrill and satisfaction of working in this effective institution.

Innovative organizations need leaders who have these characteristics: possessing a clear vision, determination, and a concerned for the organization's future ability;, to identify key sources, networks and needs as well as; looking for alternatives to make a change; taking initiatives to modify and develop themselves; , thinking and acting in new ways;, ability to motivate others and show a commitment to achieve a clear goal. The leaders will set a direction, giving priority to innovation, and influence things for innovation to thrive (Watt, 2002). A leader of an educational institution should be capable of creating an effective and caring climate that will positively affecting the achievement of students; and it can be successfully carried out through the support and development as well as implementation of an efficient and effective organizational process. Based on a study by Moolenaar, Daly, and Diego (2010), although the present education system continues to grow and the school climate is improving the climate the foster innovative leadership behaviors is not given much attention.

The study by Watt (2002) outlines the characteristics of an innovative culture for the organization;, the attitude of openness to share ideas and make new things;, working together and share sharing results; good relations between the staff members; spirit of trust and closeness between professional instructors and administrators, and the practice of celebrating success, no matter big or small. According to a review of Mohamed Sani and Mumtaz Begum (2008), there is a human dimension in the climate processes, organizational components, formation of leadership vision, mission and goal based values; it has a far-reaching implication that leadership with integrity is required and integrity is needed in the formation of the organizational climate, organizational processes, and attaining the total quality. 
Factors that influence the innovative organizational climate are as follows (Watt, 2002):

1. Consideration

Consideration refers to the friendliness from the top. This also reflects the willingness on a leader to personally do a little additional improvement to the lower-level staff of an organization.

2. Intimacy

Intimacy refers to a deep sense of friendship, working relationship among the members of an educational institution.

3. Retreat

Retreat refers to the tendency of the faculty members to adopt negative attitudes in undertaking the tasks assigned to them. It also describes the behavior of lip service or not doing the assignments with full responsibility.

4. Emphasis on Production

Emphasis on production refers to a rather limited environment, in which teachers are given a bit of freedom. Such an environment is characterized by stringent regulations, and the management encourages feedback from faculty members about their working environment.

Based on this study, the researchers found that there are attributes that leaders need to adopt in order to maintain sustainability in an innovative organizational climate. Some of the attributes are as follows:
a. Effective communication
b. Teamwork
c. Inter-department collaboration
d. Reflection and supports for innovation
e. Leader have clear vision
f. Thinking and acting in new ways
g. Ability to motivate other
h. Show commitment
i. Working together
j. Share ideas and sharing results
k. Good correlation between staff

Therefore, the recommendations for the appropriate leadership styles that related to innovative and sustainable organization in institution of TVET in Malaysia are transformational leadership, innovative leadership, entrepreneurial leadership, strategic leadership, authentic leadership, participative leadership and democratic leadership.

\section{THE CONCLUSION}

A number of studies have been carried out by researchers in respect of innovation leadership attributes associated with a variety of leadership styles viewed from different perspectives. Innovation leadership plays an important role in improving the organizational performance. Therefore, the development of innovation leadership needs to be encouraged at all levels of the educational leadership. The appropriate leadership styles that related to innovative organization in institution of TVET in Malaysia are 
transformational leadership, innovative leadership, entrepreneurial leadership, strategic leadership, authentic leadership, participative leadership and democratic leadership. On the other hand, it is also necessary for an organization to develop innovative thinking among the team members so that they can excel in the jobs and remain competitive in the face of a rapidly changing world and the advent of a latest technology. Moreover, an innovative TVET leader is instrumental in nurturing the creative and innovative culture of the organizations. As a result, from these recommendations, the organizational goals are achieved by efficient future TVET leaders who are experts in administration, management, and making changes in TVET organizations.

\section{REFERENCES}

Alsolami, H. A., Guan Cheng, K. T., \& M. Ibn Twalh, A. A. (2016). Revisiting Innovation Leadership. Open Journal of Leadership. https://doi.org/10.4236/oj1.2016.52004

Authors, F. (2016). International Journal of Sustainability in Higher Education Article information: International Journal of Sustainability in Higher Education, 15(4), 450-472. https://doi.org/10.1108/14676371311312905

Avolio, B. J., \& Gardner, W. L. (2005). Authentic leadership development: Getting to the root of positive forms of leadership, 16, 315-338. https://doi.org/10.1016/j.leaqua.2005.03.001

Azanza, G., Moriano, J. A., \& Molero, F. (2013). Authentic leadership and organizational culture as drivers of employees' job satisfaction. Revista de Psicología Del Trabajo y de Las Organizaciones. https://doi.org/10.5093/tr2013a7

Babić, V. M., Savović, S. D., \& Domanović, V. M. (2014). Transformational leadership and post-acquisition performance in transitional economies. Journal of Organizational Change Management, 27(6), 856-876. https://doi.org/10.1108/JOCM-02-2014-0028

Bagheri, A., \& Pihie, Z. A. L. (2012). Entrepreneurial leadership competencies development among malaysian university students: The pervasive role of experience and social interaction. Pertanika Journal of Social Science and Humanities, 20(2), 539-562.

Bhattacharyya, S. (2006). Entrepreneurship and innovation: How leadership style makes the difference? Vikalpa, 31(1), 107-115. https://doi.org/10.1177/0256090920060109

Daniel, A. (2013). Innovation Leadership : California Management Review, 50(1), 120-144.

Edokpolor, J. E., \& Dumbiri, D. N. (2019). Resource Adequacy and Utilization for Teaching and Learning Effectiveness in Vocational Education Programmes in South-South Nigerian Universities. Journal of Vocational Education Studies (JOVES), 2(1), 1-12. p-ISSN: 2614-7483, e-ISSN: 2614-7475, DOI: https://doi.org/10.12928/joves.v2i1.727.

Elrehail, H., Emeagwali, O. L., Alsaad, A., \& Alzghoul, A. (2018). The impact of Transformational and Authentic leadership on innovation in higher education: The contingent role of knowledge sharing. Telematics and Informatics. https://doi.org/10.1016/j.tele.2017.09.018

Feng, C., Huang, X., \& Zhang, L. (2016). A multilevel study of transformational leadership, dual organizational change and innovative behavior in groups. Journal of Organizational Change Management, 29(6), 855877. https://doi.org/10.1108/JOCM-01-2016-0005

García-Morales, V. J., Jiménez-Barrionuevo, M. M., \& Gutiérrez-Gutiérrez, L. (2012). Transformational leadership influence on organizational performance through organizational learning and innovation. Journal of Business Research, 65(7), 1040-1050. https://doi.org/10.1016/j.jbusres.2011.03.005

Grojean, M. W., Resick, C. J., Dickson, M. W., \& Smith, D. B. (2004). Leaders, Values, and Organizational Climate : Examining Leadership Strategies for Establishing an Organizational Climate Regarding Ethics, 223-241.

Hadijah, A. (2015). Leadership in TVET for the 21st Century: Challenges, Roles and Characteristics. Procedia Social and Behavioral Sciences, 195(January), 1471-1476. https://doi.org/10.1016/j.sbspro.2015.06.446

Halpin, A. W. (1967). Journal of Educational Administration.

Holloway, J. B. (2012). Leadership Behavior and Organizational Climate: An Empirical Study in a Non-Profit Organization. Emerging Leadership Journeys, 5(1), 9-35.

Horth, D., \& Buchner, D. (2014). Innovation Leadership: How to use innovation to lead effectively, work collaboratively and drive results. Center for Creative Leadership, 1-20.

Hoy, W. K. (2016). Organizational Climate and Culture : A Conceptual Analysis of the School Workplace, (May). https://doi.org/10.1207/s1532768xjepc0102

Irdayanti, M. N., Ramlee, M., \& Abdullah, Y. (2015). Membangunkan Instrumen Kepimpinan Dalam Sistem Pendidikan Teknik Dan Vokasional : Penggunaan. Journal of Quality Measurement and Analysis, 11(1), $41-47$. 
Jones, O., \& Crompton, H. (2009). Enterprise logic and small firms: a model of authentic entrepreneurial leadership. Journal of Strategy and Management, 2(4), 329-351. https://doi.org/10.1108/17554250911003836

Khodori, A. (2013). Pengurusan Pentaksiran Berasaskan Sekolah: Kepemimpinan Pentaksiran Holistik Memacu Modal Insan Kreatif dan Inovatif. (Zaiton Ismail, Ed.) (Cetakan Pe). Genting Highlands, Pahang: Pusat Dokumentasi dan Sumber Pendidikan, Institut Aminuddin Baki.

Kuratko, D. F. (2007). Entrepreneurial Leadership in the 21st Century. Journal of Leadership \& Organizational Studies, 13(4), 1-11. https://doi.org/10.1177/10717919070130040201

Madhukar, V. (2017). Organisational Climate: A Conceptual Perspective. Article in International Journal of Management and Business, (August 2017). Retrieved from https://www.researchgate.net/publication/325057614

Marron, J. M. (2014). What Is An Innovative Educational Leader? Contemporary Issues In Education Research Second Quarter, 7(2), 145-150.

Martin, M. M. (2019). The Implementation of School-Based Management in Public Elementary Schools. Asian Journal of Assessment in Teaching and Learning, 9(1), 44-56. ISSN2232-1926/eISSN 2600-870X

Mohamed Sani, I., \& Mumtaz Begum, A. K. (2008). Kesan Integriti Kepemimpinan Dan Pengurusan Kualiti Menyeluruh (Tqm) Dimensi Kemanusiaan Terhadap Iklim Proses Organisasi: Satu Kajian Kes. Jurnal Pengurusan Dan Kepimpinan Pendidikan, 41-60. Retrieved from http://eprints.iab.edu.my/v2/88/1/KESAN_INTEGRITI_KEPEMIMPINAN_DAN_PENGURUSAN_KU ALITI_MENYELURUH_\%28TQM\%29_DIMENSI_KEMANUSIAAN_TERHAD̄̄AP_IKLIM_PRŌSES ORGĀNISASI.pdf

Mokhber, M., Khairuzzaman, W., \& Vakilbashi, A. (2018). Leadership and innovation: The moderator role of organization support for innovative behaviors. Journal of Management and Organization, 24(1), 108-128. https://doi.org/10.1017/jmo.2017.26

Moolenaar, N. M., Daly, A. J., \& Diego, S. (2010). The Principal Position : Innovation in schools Occupying the Principal Position: Examining Relationships Between Transformational Leadership , Social Network Position , and Schools ' Innovative Climate, (February 2017). https://doi.org/10.1177/0013161X10378689

Mua'azam, M., Yahya, D., \& Siti Noor, I. (2016). Kepimpinan Strategik Dan Hubungannya Dengan Kesediaan Perubahan Warga Organisasi. Jurnal Kepimpinan Pendidikan, Bil 3(2), 1-14.

Para-González, L., Jiménez-Jiménez, D., \& Martínez-Lorente, A. R. (2018). Exploring the mediating effects between transformational leadership and organizational performance. Employee Relations. https://doi.org/10.1108/ER-10-2016-0190

Rahman, M. A. (2016). Organization Strategies \& Innovative Leadership Management. International Journal of Business and Management, 11(10), 206. https://doi.org/10.5539/ijbm.v11n10p206

Razak, N. A. B. A., Jaafar, S. N. B., Hamidon, N. I. B., \& Zakaria, N. B. (2014). Leadership Styles of Lecturer's Technical and Vocational in Teaching and Learning. Journal of Education and Practice.

Richter, N., Jackson, P., \& Schildhauer, T. (2018). Entrepreneurial Innovation and Leadership: Preparing for a Digital Future. Entrepreneurial Innovation and Leadership: Preparing for a Digital Future. https://doi.org/10.1007/978-3-319-71737-1

Roomi, M. A., \& Harrison, P. (2011). Entrepreneurial Leadership : What Is It and How Should It Be Taught? International Review of Entrepreneurship, 9(3), 1-43.

Sarros, J. C., Cooper, B. K., \& Santora, J. C. (2008). Through Transformational Leadership and Organizational Culture. Journal of Leadership \& Organizational Studies, 15(2), 145-158. https://doi.org/10.1177/1548051808324100

Schoemaker, P. J. H., Heaton, S., \& Teece, D. (2018). Innovation, Dynamic Capabilities, and Leadership. California Management Review. https://doi.org/10.1177/0008125618790246

Schuckert, M., Kim, T. T., Paek, S., \& Lee, G. (2018). Motivate to innovate: How authentic and transformational leaders influence employees' psychological capital and service innovation behavior. International Journal of Contemporary Hospitality Management. https://doi.org/10.1108/IJCHM-05-2016-0282

Sharma, R. (2005). Identifying a Framework for Initiating, Sustaining and Managing Innovations in Schools. Psychology and Developing Societies, 17(1), 51-80. https://doi.org/10.1177/097133360501700104

Sheard, G., Kakabadse, A., \& Kakabadse, N. (2016). Leadership teams: Developing and sustaining high performance. Leadership Teams: Developing and Sustaining High Performance. https://doi.org/10.1057/9780230239487

Somech, A. (2006). The effects of leadership style and team process on performance and innovation in functionally heterogeneous teams. Journal of Management, $132-157$. https://doi.org/10.1177/0149206305277799

Stevenson, J., \& Kaafarani, B. (2012). Breaking away: A new model for innovation. Leader to Leader. https://doi.org/10.1002/lt1.20022 
Suriyati Yaapar, S. A. K. \& M. I. N. (2018). Keprihatinan (Concern) Guru Kolej Vokasional Terhadap Transformasi Pendidikan Teknik dan Vokasional. Jurnal Penyelidikan Pendidikan, Jilid 19, $258-271$. https://doi.org/ISSN 1511-6530

Terblanche, T. E. (Du P. (2017). Technical and Vocational Education and Training (TVET) Colleges in South Africa: A Framework For Leading Curriculum Change. Stellenbosch University.

Watt, D. (2002). How innovation occurs in high schools within the network of innovative schools: The four pillars of innovation research project. The Conference Board of Canada. Retrieved from http://www.schoolnet.ca/nis-rei/e/research/pillars/index.asp

Woolley, L., Caza, A., \& Levy, L. (2011). Authentic Leadership and Follower Development: Psychological Capital, Positive Work Climate , and Gender. https://doi.org/10.1177/1548051810382013

Zhou, F., \& Wu, Y. J. (2018). How humble leadership fosters employee innovation behavior: A two-way perspective on the leader-employee interaction. Leadership and Organization Development Journal, 39(3), 375-387. https://doi.org/10.1108/LODJ-07-2017-0181

Zuraik, A. (2017). A Strategic Model For Innovation Leadership : Ambidextrous and Transformational Leadership Within A Supportive Climate To Foster Innovation Performance. A Dissertation Presented to the Faculty of the California School of Management \& Leadership.

Zaidatul Akmaliah Lope Pihie dan Amir Sadeghi (2012). Leadership in Relation to SchoolProductivity, Stress and School Culture dalam Educational Leadership Performance \& Improvement oleh Zaidatul Akmaliah Lope Pihie \& Asfaneh Bagheri. Serdang: Universiti Putra Malaysia Press. 